\title{
Analisis Pengaruh Perubahan Number Scan Average Terhadap Signal to Noise Ratio Pada Citra MRI Brain Sekuen T2 Fast Spin Echo (FSE)
}

\author{
Rakhmat Kurniawan $^{1}$, Puji Hartoyo ${ }^{2}$, Ni Larasati Kartika Sari ${ }^{2}$ \\ ${ }^{1}$ Instalasi Radiologi RS Premier Bintaro \\ ${ }^{2}$ Jurusan Fisika. Fakultas Teknik dan Sains Universitas Nasional, Jakarta. \\ Korepondensi: nilarasati@civitas.unas.ac.id
}

\begin{abstract}
Abstrak. Telah dilakukan penelitian tentang pengaruh perubahan nilai parameter Number Scan Average (NSA) terhadap kualitas citra MRI yang direpresentasikan oleh nilai Signal to Noise Ratio (SNR). Penelitian dilakukan menggunakan citra otak potongan aksial menggunakan sekuen T2 Fast Spin Echo. Variasi nilai NSA yang digunakan adalah 2, 4 dan 6. Nilai SNR dihitung memanfaatkan algoritma median filter pada software Matlab 2013a. SNR diperoleh dengan membandingkan nilai piksel rata-rata dari citra setelah diberi median filter dengan nilai piksel rata-rata dari selisih citra sebelum dan sesudah diberi median filter. Nilai SNR pada NSA 2,4 dan 6 masing-masing sebesar 81,3411, 85,8796, dan 87,2757. Hal tersebut menunjukkan bahwa semakin besar nilai NSA, semakin besar pula nilai SNR yang diperoleh. Kenaikan NSA dari 2 ke 4, meningkatkan NSA sebesar 5,6\%, dan perubahan NSA dari 4 ke 6, meningkatkan SNR sebanyak 1,6\%. Namun, kenaikan nilai NSA juga menambah waktu scanning. Kenaikan NSA dari 2 ke 4, dan 4 ke 6, menambah waktu scanning rata-rata sebesar 2 menit.
\end{abstract}

Kata Kunci: nilai piksel, median filter, kualitas citra, citra MRI, fast spin echo.

\begin{abstract}
This study evaluates the effect of Number Scan Average (NSA) to the image quality, represent by the value of Signal to Noise Ratio (SNR). Brain MRI images obtained by changing the NSA value to 2, 4, and 6 were used. Median filter algorithm in Matlab 2013 a software was also used to measure the SNR values. The SNR values were the ratio of median filtered image's mean pixel value to the difference of original image's mean pixel value and median filtered image's mean pixel value. The SNR of NSA 2, 4, and 6 are 81.3411, 85.8796, and 87.2757 each. It shows that the greater value of NSA, the greater value of SNR obtained. Changing the NSA from 2 to 4, increase 5.6\% of the SNR, and changing the NSA from 4 to 6 , increase $1.6 \%$ of the SNR. But, increasing the NSA value will also increase the scanning time. Changing the NSA from 2 to 4 and 6 will increase 2 minutes of the average scanning time.
\end{abstract}

Keywords: pixel value, median filter, image quality.

\section{PENDAHULUAN}

MRI (Magnetic Resonance Imaging) merupakan teknik yang mengkombinasikan teknologi komputer, medan magnet yang kuat dan gelombang radio untuk menghasilkan gambaran yang tajam dan jelas dari jaringan internal tubuh [1]. Kualitas citra MRI yang optimal ditentukan oleh tiga karakteristik, yaitu kontras citra, spatial resolusi, dan Signal to Noise Ratio (SNR). SNR adalah ukuran yang membandingkan tingkat sinyal yang diinginkan dengan tingkat noise latar belakang. Dengan memvariasikan beberapa variabel pencitraan, bidang pandang (Field of View/FOV), parameter scan, kekuatan medan magnet dan ketebalan irisan, SNR dari gambar MRI dapat ditingkatkan karena parameter ini mempengaruhi kebisingan latar belakang. Hubungan SNR dengan variabel hardware seperti kekuatan medan magnet dan jenis kumparan, diantaranya adalah SNR meningkat hampir linear dengan kekuatan medan [2] dan juga jenis kumparan yang digunakan [3].

Parameter scan seperti echo train length (ETL) juga berpengaruh terhadap kualitas citra MRI. Peningkatan nilai ETL akan meningkatkan nilai SNR dan CNR pada citra MRI lumbal sagital yang diambil dengan menggunakan pembobotan T2 FSE 
(Fast Spin Echo) [4]. Selain itu, parameter scan berupa TE dan TR juga mempengaruhi nilai SNR. Nilai SNR mengalami kenaikan secara eksponensial untuk nilai TR dari $100 \mathrm{~ms}$ hinggaa $700 \mathrm{~ms}$ dan stabil pada TR berikutnya hingga $4000 \mathrm{~ms}$ [5]. Number Scan Average (NSA) juga merupakah salah satu parameter scan yang mempengaruhi kualitas citra MRI [6]. Meningkatkan NSA dapat meningkatkan nilai SNR pada citra daerah korpus, medulla spinalis dan diskus intervertebralis yang diambil dengan pembobotan T1 sekuens spin echo [7].

Penelitian ini mengevaluasi pengaruh perubahan NSA terhadap nilai SNR. Penelitian ini menggunakan sampel pada citra MRI Brain yag diambil dengan menggunakan sekuen T2 Fast Spin Echo. Nilai SNR diukur dengan memanfaatkan algoritma median filter pada software Matlab 2013a.

\section{BAHAN DAN METODE PENELITIAN}

Pesawat MRI yang digunakan pada penelitian ini adalah Philip Achieva dengan kekuatan magnet (Magnet Strength) 1.5 Tesla. Citra yang digunakan dalam penelitian ini adalah 5 sampel potongan axial dengan slice $5 \mathrm{~mm}$ dengan perubahan nilai NSA 2, 4 dan 6 pada pemeriksaan MRI Brain tanpa kontras sekuens T2 FSE (Fast Spin Echo) . Jumlah sampel adalah sampel sebanyak 5 pasien berjenis kelamin pria dengan range usia 20-30 tahun. Pada setiap citra MRI potongan axial dengan variasi NSA, dipilih satu irisan yang paling mewakili pada slice ke 10 dimana memvisualisasikan obyek cerebelum secara menyeluruh dan lebih jelas, seperti pada gambar 1. Nilai SNR dihitung memanfaatkan algoritma median filter pada software Matlab 2013a. SNR diperoleh dengan membandingkan nilai piksel rata-rata dari citra setelah diberi median filter dengan nilai piksel rata-rata dari selisih citra sebelum dan sesudah diberi median filter.

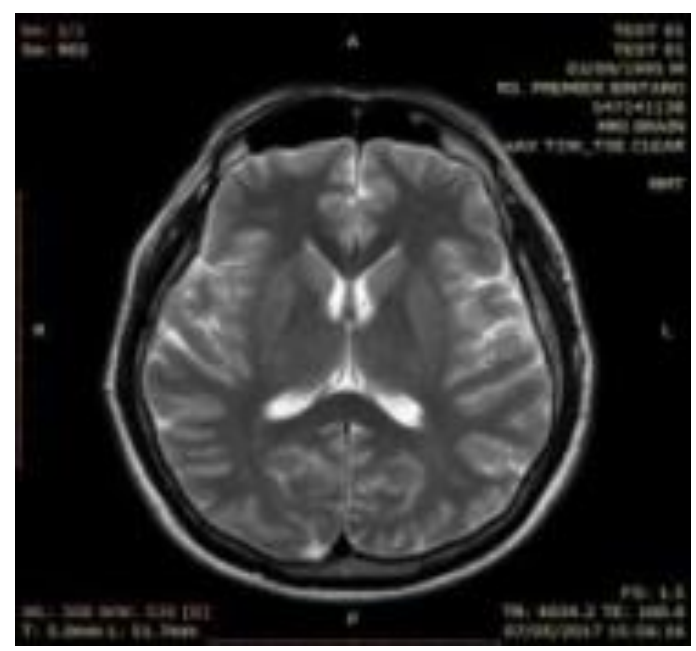

Gambar 1. Contoh Sampel Citra MRI Brain NSA 2 pada irisan ke-10.

\section{HASIL DAN PEMBAHASAN}

Setelah mendapatkan citra hasil scanning dilakukan pengukuran Signal Noise Ratio (SNR) menggunakan software Matlab R2013a. Nilai SNR diperoleh dengan membandingkan nilai signal dengan noise, dimana nilai piksel rata-rata pada citra yang telah di-filter dengan median filter merupakan signal, sedangkan noise merupakan selisih nilai piksel rata-rata citra asli dengan citra yang telah di-filter.

Hasil dari pengukuran nilai SNR variasi NSA 2, 4, dan 6 terhadap sampel 1 hingga 5 dapat dilihat pada tabel 1. Berdasarkan tabel 1, terdapat perbedaan hasil nilai SNR pada masing-masing sampel yang telah dilakukan. Pada gambar 2 terlihat bahwa nilai SNR akan meningkat seiring dengan peningkatan NSA. Dimana nilai rata-rata SNR 81,3411 pada NSA 2 meningkat menjadi 87,2757 pada NSA 4 dengan persentase 5,6 $\%$. 
Sedangkan nilai SNR pada NSA 6 terjadi peningkat dengan persentase 1,6\% dengan nilai SNR 87,2757.

Tabel 1. Nilai SNR pada kelima sampel dengan variasi NSA 2, 4, dan 6.

\begin{tabular}{cccc}
\hline \multirow{2}{*}{ Sampel } & \multicolumn{3}{c}{ Signal to Noise Ratio (SNR) } \\
\cline { 2 - 4 } & NSA 2 & NSA 4 & NSA 6 \\
\hline Citra 1 & 78,6452 & 83,9600 & 86,6756 \\
Citra 2 & 80,6702 & 85,5918 & 87,4051 \\
Citra 3 & 82,2016 & 86,9710 & 89,9870 \\
Citra 4 & 80,9534 & 84,5271 & 80,9534 \\
Citra 5 & 84,2353 & 88,3479 & 91,3572 \\
\hline Rata-rata & 81,3411 & 85.8796 & 87.2757 \\
\hline
\end{tabular}

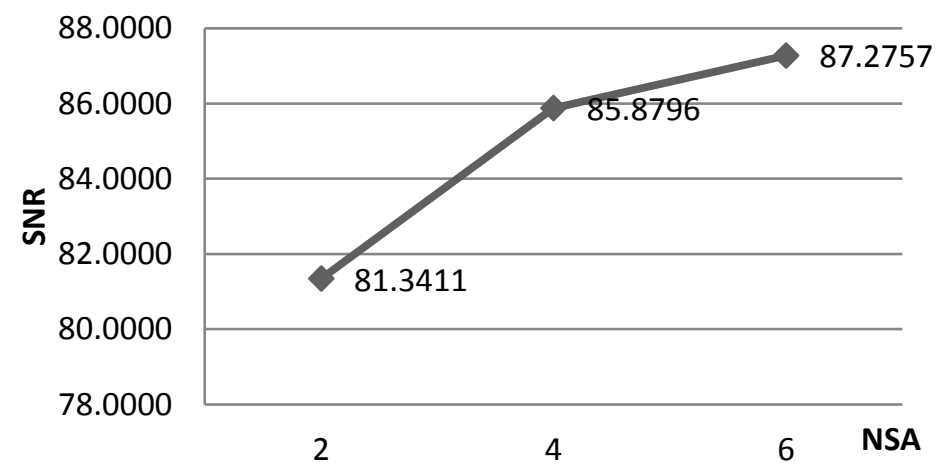

Gambar 2. Grafik Nilai SNR pada 5 sampel dengan variasi NSA 2,4 dan 6 pada Metode 2

Selain pengaruh variasi NSA terhadap SNR yang berbeda, efek terjadinya peningkatan nilai NSA 2, 4, dan 6 juga berpengaruh terhadap waktu pencitraan. Pada tabel 2 dapat dilihat terjadinya peningkatan waktu pencitraan pada pemeriksaan MRI Brain Non Contrast dengan sekuens T2 Fast Spin Echo (FSE). Pengaruh kenaikan NSA terhadap waktu pencitraan (scanning time) dapat dilihat pada tabel 2.

Tabel 2. Waktu scanning pada kelima sampel dengan variasi NSA 2, 4, dan 6.

\begin{tabular}{|c|c|c|c|c|c|c|}
\hline \multirow{2}{*}{ NSA } & \multicolumn{5}{|c|}{ Waktu scanning (menit) } & \multirow{2}{*}{$\begin{array}{c}\text { Rata-rata } \\
\text { (menit) }\end{array}$} \\
\hline & Citra 1 & Citra 2 & Citra 3 & Citra 4 & Citra 5 & \\
\hline 2 & 1,57 & 1,57 & 1,57 & 1,57 & 1,57 & 1,57 \\
\hline 4 & 3,5 & 3,5 & 3,5 & 3,5 & 3,5 & 3,5 \\
\hline 6 & 5,42 & 5,42 & 5,42 & 5,42 & 5,42 & 5,42 \\
\hline
\end{tabular}

Pada tabel 2, terjadinya peningkatan waktu pada variasi NSA 2,4, dan 6. Waktu pengambilan citra pada NSA 2 pada semua sampel mengalami persamaan waktu scanning selama 1.57 menit. Hal tersebut juga terjadi pada NSA 4 dimana waktu scanning 3.5 menit pada MRI brain lebih lama dibandingkan NSA 2 dengan selisih waktu scanning 1.93 menit. Sedangkan waktu scanning pada NSA 6 lebih lama dibandingkan NSA 4 selama 5.42 menit dengan selisih waktu 1.92 menit. Dari semua sampel, didapat rata-rata lamanya waktu scanning pada variasi NSA 2 selama 1.57 menit, NSA 4 selama 3.5 menit dan NSA 6 didapat 5.42 menit sehingga terjadi perbedaan waktu rata-rata pada saat scanning. Hasil rata-rata tersebut dapat dilihat pada gambar 3.

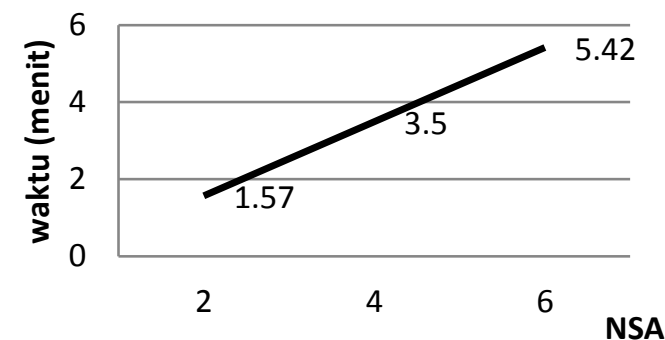

Gambar 3. Grafik rata-rata waktu scan pada NSA 2, 4 dan 6 
Gambar 3 menunjukan perbedaan waktu scanning rata-rata pada variasi NSA 2, 4 dan 6. Semakin besar nilai NSA, maka waktu scanning juga akan bertambah. Kenaikan NSA 2 ke 4, meningkatkan waktu scanning sebesar 55.14\%. Sedangakan perubahan NSA dari 4 ke 6 meningkatkan waktu scanning sebesar 35.42.

\section{KESIMPULAN}

Berdasarkan hasil penelitian diperoleh bahwa semakin besar nilai NSA, semakin besar pula nilai SNR yang diperoleh. Kenaikan NSA dari 2 ke 4, meningkatkan NSA sebesar 5.6\%, dan perubahan NSA dari 4 ke 6, meningkatkan SNR sebanyak 1.6\%. Namun, kenaikan nilai NSA juga menambah waktu scanning. Kenaikan NSA dari 2 ke 4, dan 4 ke 6 , menambah waktu scanning rata-rata sebesar 2 menit.

\section{DAFTAR PUSTAKA}

[1] Soeharto, I. 2004. Penyakit Jantung Koroner dan Serangan Jantung. Edisi Kedua. Jakarta: PT Gramedia Pustaka Utama.

[2] Vanel, D., \& McNamara, M. T. 1989. MRI of the Body. Berlin: Springer-Verlag.

[3] Woodward, P. and William, W. A., 1997, MRI Optimization, a hand on approach, McGraw-Hill, Co. USA

[4] Simanjuntak, Josepa ND. Et al. 2014. Studi Analisis Echo train Length Dalam KSpace serta pengaruh Terhadap Kualitas Citra Pembobotan T2 FSE Pada MRI 1.5 T. Universitas Diponegoro Semarang.

[5] Prastowo Alan. Setiabudi Wahyu. Anam Choirul. 2013. Kolerasi Nilai Time Repetition (TR) dan Time Echo (TE) Terhadap Signal To Noise Ratio (SNR) Pada Citra MRI. Berkala Fisika : Vol.16 No.4

[6] Notosiswoyo, Mulyono, 2004, Media Litbang Kesehatan : Pemanfaatan Magnetic Resonance Imaging (MRI) Sebagai Sarana Diagnosa Pasien, Volume XIV, Nomor 3.

[7] Kartawiguna, D. 2015. Tomografi Resonansi Magnetik Inti: Teori dasar, Pembentukan Gambar dan Instrumentasi Perangkat Kerasnya. Yogyakarta: Graha Ilmu. 